\title{
HET LEENSTELSEL VAN DE WESTINDISCHE COMPAGNIE.
}

\author{
DOOR Mr. G. J. FABIUS.
}

\section{De Patronaten.}

De Westindische Compagnie verkreeg bij haar octrooi in 1621 niet alleen de vrije vaart naar, en de uitoefening van het bestuur over de haar toegestane gewesten, maar zij zag zich daarvan ook den eigendom toegewezen. Het toekennen van eigendomsrechten op een groot gedeelte van den aardbol moge naar onze tegenwoordige begrippen eenigszins zonderling schijnen, destijds had het gezonden zin. Immers de Staat gaf op deze wijze voor alle toekomstige gevallen toestemming voor het inbezitnemen van in zee ontdekte, onbekende landen, die volgenś het OudHollandsch recht van hem werd gevorderd (Voet: De Acquir. dom. n. 17. 1. 41. t). Tevens deed hij in eens en voorgoed afstand van het hem toekomende eigendomsrecht op veroverden grond (De Groot, Inl. II. IV. 35 en De Jure B \& P.: L 3. C 6. 11).

Voor de gewesten waarin de Compagnie zich bleef bepalen tot het onderhouden van grootere of kleinere factorijen was verdere overdracht van recht onnoodig. Zulks was het geval op de westkust van Afrika, alwaar de eerste Compagnie, met het oog op den slavenhandel, zelfs de vaart en den handel van particulieren streng verbood (Bijdr. Hist. Gen. XXXV. 87). De geleidelijke beperking en ten slotte de opheffing van het slavenmonopolie onder de tweede Compagnie van 1674, alsmede de algeheele verdwijning van den slavenhandel in latere tijden brachten in den toestand van onze Afrikaansche nederzettingen weinig verandering. Van werkelijke kolonisatie is daar nimmer iets gekomen. Zelfs het gebied, dat wij in 1871 aan Engeland afstonden, was tot op het laatst een zuivere bestuursvestiging gebleven.

Op het Amerikaansche gebied van de Compagnie ontwikkelde de toestand zich geheel anders. De vestigingen droegen aldaar 
van den aanvang af, of althans reeds zeer spoedig, het karakter van volkplantingen. De Compagnie kon daardoor niet ontkomen aan de noodzakelijkheid om aan haar kolonisten eenig recht te verleenen op den grond. Maar welk? Droeg zij den eigendom over, dan liep zij gevaar al haar rechten te verliezen, want men onderscheidde destijds nog niet zoo scherp tusschen publiek en privaatrecht en zocht, op het voetspoor van het Romeinsche recht, in een min of meer denkbeeldigen eigendom den rechtsgrond voor zijn gezag over vreemde landen. Er was dus een andere oplossing noodig en die vond men in het zoogenaamde leenrecht, waarvan destijds ten onzent nog vele overblijfsels bestonden. Ook andere koloniseerende mogendheden hadden van het leenrecht gebruik gemaakt, in het bijzonder Engeland, waar al de rechten op den grond een feodaal karakter moesten dragen en gewone, allodiale eigendom eigenlijk zelfs nu nog niet bestaat. Maar ook afgezien daarvan was de keus van de Compagnie niet oorspronkelijk. Zij volgde blijkbaar het voorbeeld, haar door de Oostindische Maatschappij gegeven, die na de verovering van Jacatra in 1618 reeds gronden in leen had uitgegeven. Toen de W. I. C. dit stelsel begon toe te passen had het echter in Oost-Indie al weder afgedaan, althans ten aanzien van Europeanen. Immers werden in 1627 de toegekende leenrechten door den gouverneur-generaal De Carpentier in vollen eigendom veranderd. Dat de W. I. C. haar toevlucht nam tot, en bleef vasthouden aan een stelsel, dat op Java niet had voldaan, moet waarschijnlijk worden toegeschreven aan het groote verschil in den ontwikkelingsgang der beide maatschappijen. Voor de Oostindische, die voortdurend in macht en aanzien steeg, werd het theoretische eigendomsrecht een vrij onbelangrijke zaak, waarvan zij gaarne afstand deed, toen dat ter vereenvoudiging van den toestand wenschelijk bleek. De minder voorspoedige Westindische Compagnie daarentegen hechtte aan dat recht grooter waarde. $\mathrm{Zij}$ had het noodig om een schijn var. gezag te kunnen handhaven, nadat dit in werkelijkheid op haar leenmannen was overgegaan.

Uit den aard der zaak kwam het feodaal karakter van het grondrecht het sterkst uit in de gevallen dat de uitgifte van den grond geschiedde onder de verplichting om voor het bestuur er van zorg te dragen. Zulke uitgiften hadden, zooals voor de hand ligt, geen betrekking op bepaalde perceelen, maar betroffen grootere landstreken. Soms was de plaats er van zeer onvoldoende 
aangewezen en werd vergunning verleend om ergens in een zeker gewest een kolonie te gaan stichten. In de eerste jaren van het bestaan der Compagnie kwamen zulke uitgiften echter nog niet voor. Aanvankelijk streefde zij voornamelijk handels- en oorlogsdoeleinden na. Maar na betrekkelijk korten tijd kwam daarin verandering en ging zij zich ook op blijvende vestigingen toeleggen.

Met de stichters van kolonien werden oorspronkelijk overeenkomsten gesloten, die, hoeveel gelijkenis zij onderling ook mochten vertoonen, uit haar aard slechts voor één bepaald geval golden. De stichters moesten hun kolonisten van een goede instructie voorzien, welke van te voren de goedkeuring van bewindhebbers moest hebben verkregen, en onder hen een goede orde houden. In zaken van rechtspraak en bestuur (justitie en politie) waren $z i j$ echter onderworpen aan de regelen, die de Compagnie gesteld had of later zou stellen. De rechten en verplichtingen van stichters en kolonisten waren voorts zeer uitvoerig geregeld. Ten aanzien van den grond werd hun het recht verleend bosschen te vellen, te zaaien en te planten, naar delfstoffen te zoeken en voorts alles te doen, wat zij voor hun kolonie dienstig en profijtelijk zouden oordeelen. $\mathrm{Zij}$ kregen dat recht slechts voor een bepaald aantal jaren, al werd verlenging ook van hun wil afhankelijk gesteld. Maar, mocht de kolonie te eeniger tijd weder worden opgegeven, dan moest alles, ook de geprepareerde landen en het vee, overgeleverd worden in handen van de Compagnie, zonder dat de stichter of een der coloniers daarop eenigen eigendom of pretensie zou houden "noch min, noch meer, dan oft hij ofte zijne colloniers daer "nemmermeer geweest en waren» ${ }^{1}$. Overdracht van den grondeigendom aan de kolonisten lag dus allerminst in de bedoeling.

Volgens Netscher ${ }^{2}$ blijkt uit de Zeeuwsche Commissien, Instructien en Conditien van Coloniers, die zich op het Rijksarchief bevinden, dat zulke "Contracten van conditien en articulen», zooals men ze noemde, in 1626 en 1627 door de Kamer van Zeeland gesloten werden met Claude Prevost en Jan van Rijen, de stichters van onze kortstondige vestigingen aan de

1 Uitgifte van Berbice aan Van Pere, opgenomen bij Netscher, Geschiedenis van Essequebo enz. Bijlagen $\mathrm{N}^{\circ} 18$.

2 t. a. p. bl. 53 . 
Cayennerivier en de Wiapoco '. Ook voor Abraham van Pere, een aanzienlijk Vlissingsch koopman en bewindhebber der W. I. C., wiens vader reeds in 1602 vrijdom van convooi had verkregen voor de vaart op Guiana, werd nog een contract van dien aard ontworpen, dat de vestiging aan de Berbice betrof. Maar dit ontwerp, waarvan de tekst door Netscher ${ }^{2}$ wordt medegedeeld, werd de aanleiding tot een verandering in de staatkunde van de Compagnie. De Raad van XIX kon zich er namelijk niet mede vereenigen en gaf de voorkeur aan een algemeene regeling voor het stichten van volkplantingen, op grond waarvan dan in ieder geval de uitgifte zou plaats hebben. Zulk een algemeene regeling werd dan ook in zijn vergadering van 12 Juni 1627 vastgesteld. Ook deze regeling is bij Netscher ${ }^{3}$ te vinden.

Aan iederen bewindhebber, hoofd of mindere participant werd voor het vervolg toegestaan naar de wilde kust en de eilanden daar gelegen kolonies te zenden (art. 1). De gevestigde kolonies zouden staan onder een centraal gezag dat te Cajana (Cayenne) zou zetelen en zou worden uitgeoefend door een Directeur of Commandeur en een aantal door die koloniën gekozen raden (één voor ieder). Aan dit centraal gezag moesten de patroons, want zoo heetten de stichters, jaarlijks verslag uitbrengen van den toestand hunner kolonie (art. 10). Hun bestuursbevoegdheid was overigens op gelijke wijze geregeld als in de oude contracten (art. 9). Blijkens artt. 14 en 15 moesten zij voor de uitgifte van den grond zorgen en kon die grond door de kolonisten zelfs in eigendom worden verkregen. Het recht op de delfstoffen bleef echter den patroons voorbehouden (art. 18).

Vergelijkt men deze "Vrijheden en exemptien , met de vroegere contracten, dan ziet men aan den eenen kant een kleine vooruitgang in de richting van het leenrecht. De stichter draagt reeds den titel van patroon, het regaal van de delfstoffen wordt hem toegekend. Maar verder gaat het feodale karakter toch nog niet. Geen enkele jurisdictie wordt toegezegd. Van de kenmerken van het leenrecht, d. z. schut, manschap en heergewaden, wordt geen spoor aangetroffen. Zelfs is de in art. 14 onderstelde mogelijkheid van eigendomsverkrijging door de kolonisten

1 Dit was eigenlijk onze tweede vestiging aàn de Wiapoco. Van de eerste is weinig bekend.

t. a. p. Bijlagen No 18.

$s$ t. a. p. Bijlagen No 19 . 
in strijd met het beginsel der feodaliteit, al behoeft aan het woord eigendom nu niet altijd zulk een principieele zin gehecht te worden.

Maar weldra zou het leenrecht sterker op den voorgrond treden. De Raad van XIX, die langzamerhand tot het inzicht was gekomen dat de ontwikkeling van de nederzettingen in Noord-Amerika niet geheel om den pelshandel mocht worden tegengehouden, maar die daarvoor toch geen geld over had, besloot in zijn vergadering van 10 Maart 1628 (Br. I. 84) tot het maken van een algemeene regeling voor de kolonisatie van dat gebied, volgens welke de noodzakelijke uitgaven niet door haar behoefden te worden bestreden. Als uitvloeisel daarvan werd den $7^{\text {den }}$ Juni 1629 een reglement van vrijheden en exemptien vastgesteld (Br. I. 84) voor de stichters van kolonien in NieuzeNederland. Dat reglement, hetwelk eerst in 1630 bekend gemaakt schijnt te zijn (Br. II. 551), erkende als patroon ieder aandeelhouder van de Compagnie, die een kolonie van tenminste 50 man oprichtte. De patroons moesten dus de onkosten van de kolonisatie dragen. Daartegenover kregen zij echter uitgebreide bevoegdheden. Vele bepalingen betreffende hun rechtsverhouding tot de Compagnie herinneren aan de zoo juist genoemde regeling van 1627 voor West-Indie. Maar het feodale karakter van hun recht kwam nu duidelijk uit. Wel zouden zij, krachtens art. IV, boven anderen de voorkeur hebben op den vollen eigendom van de door hen uitgekozen landstreken; maar desondanks werd bij art. VI uitdrukkelijk bepaald dat zij hun land van de Compagnie zouden houden als een onsterfelijk erfleen, te verheergewaden, zoo menigmaal het op een ander overging, met f 20 per kolonie, te betalen binnen één jaar en zes weken, hetzij aan de Kamer ter plaatse waar de stichter was vertrokken, hetzij aan den Commandeur in Nieuw-Nederland. Wanneer zij het verlangden zou hun verlof verleend worden om bij uitersten wil over hun goed te beschikken. Hun recht bracht mede het recht op de delfstoffen en andere voordeelen van het land. Zij kregen jacht-, visch-, en maalrecht, met uitsluiting van ieder ander. Behalve het bestuur van hun gebied kregen zij daarover lage jurisdictie. Vonnissen, door hun gerechten geveld, waren echter aan hooger beroep op Commandeur en Raden van NieuwNederland onderworpen, indien het bedrag der zaak f 50.- te boven ging. Voor het geval in hun leen steden ontstonden kregen zij aldaar de magistraatsbestelling. 
Het gebied, dat zij onder deze voorwaarden konden bezetten, was onbeperkt. Alleen moest daarvoor een koopprijs aan de Indianen zijn betaald en mochten de zee- en riviergrenzen een zekere lengte niet te boven gaan. Ook het aan hun leen grenzende land mochten zij gebruiken, zoolang de Compagnie daarover niet ten voordeele van anderen had beschikt. Slechts het eiland Manhattan, dat de Compagnie voor zich behield, was uitgesloten.

$\mathrm{Bij}$ de krachtens deze regelen gedane uitgiften deed de Compagnie voor de toekomst afstand van alle, zelfs de geringste aanspraken op den grond, zoowel ten aanzien van den eigendom daarvan als ten opzichte van het bestuur en de jurisdictie. Toch bedoelde zij daarmede geen overdracht van den allodialen eigendom. Duidelijk blijkt dat uit de door Brodhead (I. 43 en 44) medegedeelde verleibrieven van Swaanendael en Rensselaerswijck. Behalve de zoo juist genoemde afstand van rechten kwam daarin de bepaling voor, dat de patroons werden "gesubrogeerd" in de rechten van de Compagnie op den grond. $\mathrm{Zij}$ werden volledig en onherroepelijk gemachtigd tot het rustig bezit en genot er van "tamquam Actores et Procuratores in rem propriam». $\mathrm{Nu}$ was de zoogenaamde procuratio in rem suam een fictie van het Romeinsche recht, waardoor de feitelijke overdracht van rechtens onoverdraagbare bevoegdheden mogelijk werd gemaakt. Door van deze rechtsfiguur gebruik te maken gaf de Compagnie dus te kennen dat zij haar uitsluitend eigendomsrecht op den grond in beginsel bleef handhaven, ook al kwam er in de practijk van dat beginsel weinig meer terecht.

Van de leenen, die op deze wijze ontstonden, zijn de meest bekende Swaanendael, Pavonia en Rensselaerswijck. Swaanendael, gelegen aan de Delawarebaai, werd bij octrooi van 15 Juli 1630 verleend aan Samuel Godijn en Samuel Blommaert (Br. I. 43). De aldaar gestichte kolonie werd echter reeds in het volgend jaar door de Indianen uitgemoord. In 1635 deden de patroons afstand van hun rechten. Pavonia, zoo genoemd naar den stichter Michiel Pauw, lag tegenover het fort Amsterdam op de plaats van het tegenwoordige Jersey-city. Het werd in 1637 voor f 26.000. - door de Compagnie teruggekocht (Br. I. 432). Rensselaerswijck werd bij octrooi van 13 Augustus 1630 uitgegeven (Br. I. 44). Het lag aan de Noordrivier in den omtrek van het fort Oranje, thans Albany, Bij resolutie van 5 Februari 
1641 verleenden de Staten-Generaal daarvoor venia testandi. De ondeelbaarheid van het leen werd daarbij tevens opgeheven (Br. I. 124). Bij resolutie van 7 April 1650 werd Johan van Rensselaer, de zoon van den stichter Kiliaen v. R., door de Staten-Generaal bekleed met hooge, middelbare en lage jurisdictie (Br. I. 383). Rensselaerswijck was aanvankelijk van weinig belang. Later geraakte het wel is waar tot bloei, maar veel nut had de Compagnie daarvan niet. Het verlies van Nieuw-Nederland in 1664 deed ook dit leen voor haar verloren gaan.

Het doel dat de Compagnie zich met de invoering van het leenstelsel had voorgesteld werd niet bereikt. Van de kolonisatie kwam niet veel terecht en de uitgebreide rechten van de patroons, die tot veel moeilijkheden aanleiding gaven, waren langen tijd een beletsel voor het wagen van een nieuwe proefneming. Deze moeilijkheden hebben dan ook hun stempel gedrukt op het nieuwe reglement van vrijheden en exemptiën, dat in 1640 werd afgekondigd (Br. I. 119). Bij dit reglement, waarvan de bepalingen uiteraard in hoofdzaak aan het vorige waren ontleend, behield de Compagnie zich uitdrukkelijk een menigte rechten voor en werd de bevoegdheid van haar organen nauwkeurig geregeld. De aan de patroons toegekende vrijheid in het uitkiezen van hun grond was aanzienlijk minder dan in het reglement van 1629. Dit betrof zoowel de uitgestrektheid als de plaats van hun gebied. Hun bevoegdheid om het aangrenzende land te gebruiken verviel.

Hoewel de Compagnie tegenover de nieuwe patroons dus veel sterker stond dan tegenover de oude, had zij zich toch ook een belangrijke vermindering van rechten moeten laten welgevallen. Dit stond echter niet in verband met de vroegere oneenigheden tusschen haar en de patroons, maar was een gevolg van den aandrang der Staten-Generaal, aan welke de ontwikkeling van de kolonie eigenlijk meer ter harte ging dan aan de Compagnie zelf, die slechts aan het monopolie van haar pelshandel gedacht had en daardoor de kolonisatie eigenlijk niet gunstig gezind was geweest. Deze vermindering van rechten was drieledig. Vooreerst verviel het monopolie van den pelshandel. Dan werd de hoedanigheid van patroon niet meer voorbehouden voor aandeelhouders der Compagnie, maar voor alle ingezetenen verkrijgbaar gesteld. Ten slotte werd aan de patroons de volle, allodiale eigendom van den grond toegezegd. De feodaliteit 
werd alleen voor de jurisdictie gehandhaafd. De patroons zouden hun landen voor altijd bezitten met hooge, middelbare en lage jurisdictie, jacht-, visch- en maalrecht, met dien verstande echter dat het recht op den grond allodiaal zou zijn en de jurisdictie bezeten zou worden als een onsterfelijk erfleen, dat zoowel op mannen als vrouwen kon overgaan en bij iederen, 't zij volledigen of gedeeltelijken overgang binnen één jaar en zes weken ter vergadering van den Raad van XIX of bij den Gouverneur in de kolonie verheergewaad moest worden met een paar wapenhandschoenen, te redimeeren met $\mathrm{f}$ 20.-. In de regeling van het hooger beroep op Gouverneur en Raden kwam eenige verandering. Op deze wijze verloor het leenstelsel van de Compagnie zijn voornaamsten bestaansgrond. Het behield zijn nut om de zorgen voor het bestuur aan de patroons te kunnen blijven opdragen en ook om de waardigheid van patroon door een zeker aanzien aantrekkelijk te maken, maar zijn oorspronkelijke reden, d.i. de principieele handhaving van het eigendomsrecht van de Compagnie op den grond, verviel.

Het nieuwe reglement bracht wel eenige verbetering in den toestand. Door de gunstiger bepalingen breidde de kolonisatie zich aanmerkelijk uit. De openstelling van den pelshandel lokte bovendien veel gelukzoekers. Een van de eersten, die de kolonisatie ondernam, was Cornelis Melijn, die een kolonie stichtte op het Statenciland en daarover het patronaat voerde (Br. I. 144, 190 en 250). Dit patronaat heeft een zekere bekendheid gekregen door de groote oneenigheden, die er later tusschen den patroon en den directeur Stuijvesant ontstonden. Maar lang duurde die opbloei toch niet. In den oorlog met de Indianen (1641-1643) werden de nederzettingen grootendeels verwoest en verlaten (Br. I. 190). Ten slotte bleef er weder niet veel anders over dan de vestigingen op het Compagnieseiland Manhattan.

Inmiddels was de Compagnie - ook door den tegenspoed in Brazilië - in zulk een staat van onbekwaamheid en discrediet vervallen, dat zij niet langer bij machte was de belangen van de koloniën te behartigen (Br. I. 141). Bovendien zal zij, die de kolonisatie altijd als een inbreuk op haar monopolie had beschouwd, wel niet al te veel moeite hebben gedaan om die weder tot stand te brengen. De Staten-Generaal waren dientengevolge genoodzaakt zich zeer daadwerkelijk met deze zaak in 
te laten. Onder hun invloed werd in 1650 weder een nieuw reglement van vrijheden en exemptiën vastgesteld. (Br. I. $401 \mathrm{vlg}$ ). Daarbij geraakten de patronaten een weinig op den achtergrond en werd aan de gewone kolonisten, wier ondergeschikt belang uit de vorige reglementen duidelijk was gebleken, de eerste plaats ingeruimd. De bevoegdheid om zich in de kolonie te vestigen werd tot alle inwoners van naburige landen uitgebreid. Het uitsluitend recht van de ingezetenen verviel dus. Om patroon te worden moest men een kolonie van 100 personen boven 15 jaren hebben overgebracht. Vestiging op het eiland Manhattan bleef als voorheen verboden. Om de kolonisatie aan te moedigen werden de rechten der patroons, die bij het reglement van 1640 waren ingekort, op enkele punten weder uitgebreid tot hetgeen bij het reglement van 1629 was toegezegd geweest. Zoo was de vrijheid in de keus der plaats weder grooter, zoo ook mochten de patroons weder gebruik maken van de aan hun gebied grenzende landen, totdat de Compagnie daarover ten voordeele van anderen zou hebben beschikt. Hun recht op den grond bleef allodiaal. In dit opzicht behield men dus den toestand van het reglement van 1640 , hetgeen vooral merkwaardig is omdat het nieuwe reglement voor de gewone kolonisten juist uitdrukkelijk den eigendom van den grond uitsloot, een bepaling die te voren nimmer was gemaakt. Het groote gewicht dat men voor de kolonisatie aan de patroonschappen bleef hechten blijkt duidelijk uit deze tegenstelling. De gewone kolonisten zouden hun grond slechts kunnen bekomen in erfpacht of in leen; den patroons daarentegen werd voor goed de eigendom van hun landen, met alle voordeelen daarvan, toegezegd, benevens hooge, middelbare en lage jurisdictie, met dien verstande dat het recht op den grond allodiaal zou zijn en de jurisdictie bezeten zou worden als een onversterfelijk of eeuwigdurend erfleen, te verheergewaden met een paar wapenhandschoenen, te redimeeren met f 20.Deze bepaling was geheel aan het reglement van 1640 ontleend. Natuurlijk bestond ook in andere opzichten gelijkenis tusschen de twee reglementen. Zoo werd bijv. in de regelen nopens de magistraatsbestelling en de venia testandi geen verandering gebracht.

De uitvoering van het reglement van 1650 gaf aanleiding tot groote moeilijkheden. Vooral is daardoor bekend geworden een zekere Adriaan van den Donck, die krachtens de nieuwe vrij- 
heden een aantal immigranten naar Nieuw-Nederland overbracht (Br. I. 379) en patroon werd van de kolonie Nepperhaem of Colendonck in Wetchester, waarvoor hij in 1652 van de StatenGeneraal venia testandi verkreeg (Br. I. 470). $\mathrm{Al}$ is het thans wel zeker dat de kolonisten de oorzaak van die oneenigheden te eenzijdig aan de directeuren Kieft en Stuijvesant hebben toegeschreven, toch is het buiten twijfel dat ook het bestuur van de Compagnie niet zonder schuld geweest is. Waarschijnlijk is er van die zijde zelfs wel tegenwerking in het spel geweest. Vergunning tot vestiging werd menigmaal geweigerd. In andere gevallen werd de vestiging wel toegestaan maar de uitvoering daarvan bemoeilijkt. Zoo zijn er voorbeelden van ontneming van rechten door latere, onrechtmatige verandering van den grondbrief. Ook schijnen eenmaal toegezegde grondbrieven dikwijls te zijn achtergehouden. De daardoor veroorzaakte onzekerheid omtrent hun rechten weerhield de kolonisten dan veelal van de bebouwing van hun grond.

Al die tegenwerking heeft echter toch niet kunnen verhinderen dat de bevolking na 1650 weder begon te vermeerderen en de kolonie een beteren tijd tegemoet begon te gaan, al ging het ook niet zoo snel als het gekund had. Het reglement van 1650 heeft dus zeker een nuttige uitwerking gehad. Het werd dan ook niet meer gewijzigd en gold nog toen in 1664 de kolonie Nieuw-Nederland voor ons verloren ging.

$\mathrm{Na}$ aldus in groote trekken de geschiedenis van de patroonschappen in Nieuw-Nederland te hebben nagegaan, moeten wij thans tot die in West-Indië terugkeeren, waarvoor, zooals reeds werd medegedeeld, in 1627 een reglement werd vastgesteld naar aanleiding van de voorgenomen volkplanting aan de Berbice door Abraham van Pere. Dat reglement had een algemeene strekking en moet dus ook bij volgende gelegenheden zijn toegepast. Wel verklaart Hamelberg ${ }^{1}$ nergens te hebben kunnen vinden op welke voorwaarden het eerste octrooi voor de kolonisatie van St. Eustatius werd verleend en knoopt hij daaraan het vermoeden vast, dat die voorwaarden ongeveer gelijk zijn geweest aan de latere, door hem medegedeelde bepalingen nopens de vestiging op Tabago en St. Maarten (t.a.p. II. D. 15), maar een grond voor dat vermoeden wordt door

1 De Ned. op de W. I. cil. II. blz. 11. 
hem niet opgegeven. Naar het voorkomt wijst het ontbreken van voorwaarden bij de uitgifte er veeleer op, dat men een algemeene regeling voor oogen had. Waarschijnlijk is deze algemeene regeling het reglement van 1627 geweest, want schr. heeft nergens kunnen aantreffen dat het ooit door een ander vervangen is. Afwijking daarvan was echter reeds spoedig noodzakelijk. Zoo werden door het verlies van Cayenne de bepalingen betreffende de instelling van een centraal gezag aldaar reeds zeer spoedig onuitvoerbaar. Bovendien werkte men met aanvullingsbepalingen, die dan werden opgenomen in het zoogenaamde "accoord" met den patroon, d. i. de overeenkomst waarbij deze zich aan de algemeene regeling onderwierp. Reeds bij de eerste toepassing - in het geval van Van Pere - werd op deze wijze gehandeld en op dien weg zal men later wel zijn voortgegaan. Door een en ander moet het reglement van 1627 allengs meer zijn beteekenis van algemeene regeling verloren hebben, totdat men ten slotte de voorkeur is gaan geven aan op zich zelf staande regelingen van de vrijheden en exemptien, zooals die voor Tabago en St. Maarten. Bij deze veronderstelling meent schr. het voorloopig te moeten laten. Hem ontbreken thans de gegevens om dieper op deze zaak in te gaan.

Was de Amsterdamsche handel het meest bij Nieuw-Nederland betrokken, in Zuid-Amerika en West-Indië gaf Zeeland den toon aan. De meeste leenen aldaar werden dan ook ten behoeve van Zeeuwen uitgegeven. Geen andere dan Zeeuwsche patronaten hebben er ooit eenig succes gehad.

Het belangrijkste van die patronaten is Berbice geweest. Deze kolonie werd, naar reeds werd medegedeeld, in 1627 uitgegeven aan Abraham van Pere. Het accoord met dezen patroon werd reeds den $8^{\text {sten }}$ Maart van het volgende jaar gewijzigd. Nadere regelingen werden getroffen in 1632,1640 en 1660. Bijzonderheden daaromtrent worden door Netscher niet vermeld. Na het einde van de eerste Compagnie in 1674 ontstonden er moeilijkheden. De tweede Compagnie beweerde in de leenheerlijke rechten van haar voorgangster te zijn opgevolgd, hetgeen door de patroons werd betwist. Dit geschil werd echter betrekkelijk spoedig bijgelegd. In 1678 aanvaardde de familie Van Pere de kolonie op nieuw in leen, thans van de tweede W. I. C. (H. 295). $\mathrm{Bij}$ de "Articulen en Conditien, waarop de Heeren Gecommit- 
«teerde Bewindhebberen uit de Respective Kamers van de "Generaele Geoctroyeerde Westindische Compagnie der Ver"eenigde Nederlanden, onder Authoriteit van de Hoog Mogende "Heeren Staten-Generaal derzelver Landen, hebben uitgegeven "tot een leen aan den Heer Abraham van Pere de Colonie "gelegen op de Rivier de Berbice enz." werd bepaald dat deze kolonie "met alle de aankleeven van dien Superfice, Mineralen, "Bosschagien, Rivieren, Fontenies, en wat dies meer zij ... bij "den voornoemden Heer van Pere, zijne Erven en Nakomelingen, "gedurende den tijd van het Octroy der gemelde Compagnie, "en over zulks tot den Jaare 1700 inkluijs» zou worden "ge"houden van dezelve Compagnie als een Onsterfelijk Erfleen, "met al zijne Regalen en toebehooren, Hooge, Middelbare en "Laage Jurisdictie, Tienden, Visscherijen en Malerijen, te ver"heergewaden, zoo menigmaal als het zelvige op een ander "persoon» overging "met 20 ponden tot 40 groote ieder pond, "waarvan de betalinge ten behoeve van de voorsz. Generaale "Compagnie geschieden» zou "in de Kamer van Zeeland tot "Middelburg». De voornoemde heer Van Pere, zijn erven en nakomelingen zouden "onder den Titul van Patronen de "voorz. Colonie bezorgen, bestellen en uitvoeren al het"geen 't welk tot Conservatie van dien, mitsgaders tot onder«houdinge van goede Ordre, Politie en Justitie agtervolgens "de Wetten en Costuumes deezer Landen" zou "worden ge"requireerd».

Heel lang zou de hierdoor bevestigde toestand echter niet meer duren. In 1712 werd de kolonie gebrandschat door een Fransche vloot onder den baron De Mouans (H. 304). De betaling van de voor de schatting getrokken wissels werd echter in 1713 door de patroons geweigerd. $\mathrm{Zij}$ gaven er de voorkeur aan de kolonie over te laten aan de belanghebbende reeders van de Fransche vloot, die na het sluiten van den vrede van Utrecht haar moeielijk op nieuw konden gaan bezetten en haar daarom in 1714 voor f 108.000 . - verkochten aan Nicolaas en Hendrik van Hoorn te Amsterdam en eenige anderen. Deze groep waarin één der vroegere patroons - Cornelis van Pere van Oost- en West-Souburg - iets later voor $\frac{1}{4}$ deelnam, bracht in 1720 de kolonie in een maatschappij, de zoogenaamde Societeit van Berbice. De daarna nog door de Westindische Compagnie gedane pogingen, om als leenheer te worden erkend, 
leden schipbreuk. De Societeit hield staande "dat de kolonie "iure belli aan de Franschen was overgegaan en daarna aan de "eigenaars bij intercessie van $\mathrm{H}$. Hoog Mogenden als vrij en * eigen goed was verkocht en geleverd" '. Het haar op den $6^{\text {den }}$ December 1732 door de Staten-Generaal verleende octrooi bevestigde dit standpunt. De Societeit van Berbice werd een lichaam naast de Westindische Compagnie.

Na Berbice komt als van zelf St. Eustatius ter sprake. Dit eiland toch heeft eveneens de familie Van Pere tot patroon gehad. In 1635 werd aan Jan Snouck c. s. vergunning verleend plantage te maken op St. Kruis of, indien deze plaats te onvruchtbaar bleek, op een ander eiland. Zij vestigden zich op St. Eustatius, hetgeen in 1636 door de Kamer van Zeeland werd goedgekeurd (Ham. II. D. 14). Het octrooi voor St. Eustatius, waaronder later ook Saba werd gerekend, werd verschillende malen vernieuwd. Onder de patroons traden reeds zeer spoedig op den voorgrond de ons bekende Abraham van Pere en zijn vennoot Pieter van Rhee, in wier geslachten het leen verder verbleef. (Ham II 12 en D 14-20). In den derden Engelschen oorlog (1672-1674) had het eiland zeer te lijden. Over de vraag, of de kolonisatie moest worden voortgezet, ontstond daarna geschil tusschen de twee overgebleven belanghebbenden. Als gevolg daarvan verkocht de een, de Middelburgsche predikant Cornelis Demetrius, in 1681 zijn aandeel voor f 3140 aan de (tweede) Westindische Compagnie. De ander, Isaak van Pere van West-Souburg, die de kolonisatie had willen voortzetten, deed ten slotte hetzelfde. In 1683 ging zijn aandeel voor gelijken prijs in handen van de Compagnie over. (Ham II. 42).

In verband met de Westindische patronaten moet, naast de geslachten Van Pere en Van Rhee, het Vlissingsche koopmanshuis Lampsins worden genoemd. In 1649 werden de gebroeders Adriaan en Cornelis Lampsins beleend met het eiland St. Maarten, dat reeds vele, minder ter zake doende lotgevallen had doorgemaakt en het jaar te voren tusschen ons en de Franschen was verdeeld (Ham. II. 17 en D. 31 en 32). De voor de kolonisatie vastgestelde vrijheden en exemptien, blijkens Hamelberg (II. D. 15) overeenkomende met de latere voor Tabago;

1 Resol. en Not. Boek der Directie v. Berbice 1720-1736. R. A. aangehaald door N. 166. 
kenden aan de heeren Lampsins onder den titel van patroon het bestuur over het eiland toe (art. 7) en gaven hun het recht "te mogen verkiesen ende aenvaerden oock in eygendom be"houden, soodanige partijen van landen, als sij en sijnne onder"hebbende coloniers enichsints» zouden "machtich sijn te be"bouwen tot aenqueeckinge van allerhande vruchten en gewassen, " ook beestiaelen ende vee, te reeckenen de groote ende quanti"teijt vande voorsz. landen naer het getal van persoonen, te "weeten, twee mijlen langs de custe ofte een navigable riviere "ende landwaerts in, soo verre de gelegenheijt vereyscht, voor " 100 persoonen vier mijlen ende soo naer advenant». (art. 4).

Hoe lang de gebroeders Lampsins hun rechten op St. Maarten hebben uitgeoefend is niet bekend. Volgens Hamelberg (II. 55) schijnen zij zich na 1660 daarvan niets meer te hebben aangetrokken. Dit staat wellicht in verband met de omstandigheid dat zij inmiddels het grootere en belangrijkere eiland Tabago in leen hadden bekomen.

Op Tabago of Nieuzw-Walcheren hadden de Zeeuwen omstreeks 1627 reeds een kolonie gesticht onder het patronaat van den Vlissingschen burgemeester Jan de Moor (N. 56). Ook het huis Lampsins schijnt er iets later kolonisten heen gezonden te hebben (Versl. II. 109). Maar deze vestigingen waren niet van langen duur geweest. In 1634 werden de Nederlanders door de Spanjaarden van het eiland verdreven (Versl. IV. 15), hetgeen waarschijnlijk aanleiding heeft gegeven tot de vroegste nederzettingen op St. Eustatius en St. Maarten. Het duurde ongeveer 20 jaren voordat wij er weder vasten voet kregen. In 1655 werden de reeds genoemde gebroeders Lampsins met het eiland beleend onder gelijke voorwaarden als waarop hun eenige jaren te voren het patronaat over St. Maarten was toegekend. Het rustig bezit van Tabago was hun echter ook daarna niet gegund. De kolonie was het tooneel van herhaalden strijd. Zoowel de Engelschen als de Franschen deden aanspraken op het bezit er van gelden. Van de Compagnie konden de patroons geen voldoenden steun meer verwachten. Daarom nam Cornelis Lampsins, ter versterking van zijn rechten, in 1663 het eiland bovendien van Lodewijk XIV in leen en ontving daarbij den titel van Baron van Tabago. Maar nadat de kolonie desondanks in 1677 door de Franschen onder den admiraal D'Estrées verwoest was, verkochten de patroons op 26 October van hetzelfde jaar hun rechten aan de 
Staten-Generaal (Elias II 979). De hierdoor ontstane toestand was slechts van korten duur. Bij den vrede van Nijmegen in 1678 werd het eiland aan de Franschen afgestaan. (N. B. 34).

Maar ook aan anderen dan Zeeuwsche kooplieden werden in West-Indië leenen uitgegeven. Cayenne - waar, een zestal jaren na de mislukte kolonisatie van Claude Prévost (1626), buiten de Compagnie om een tweede, eveneens mislukte vestiging had plaats gehad door David Pietersz. de Vries (1632) - werd in de jaren 1656/7 ten derden male door de Nederlanders, thans onder Gerrit Spranger, bezet. De voorwaarden, waaronder die vestiging tot stand kwam, heeft schr. dezes nergens aangetroffen; zeer bekend daarentegen is de uitgifte van een ander gedeelte van Cayenne aan de Foden onder David Nassy, die korten tijd later plaats had. Onze nieuwe kolonie toch werd reeds spoedig een toevluchtsoord voor vele Joden uit Brazilië, die het vrijzinnige bestuur der Nederlanders aldaar op prijs hadden leeren stellen en die, na de herovering van dat land door de Portugeezen (1654), vandaar wegtrokken. Den $12^{\text {den }}$ September 1659 werd door den Raad van XIX voor hen een reglement van vrijheden en exemptien vastgesteld (H. 940 vlg.). Daarbij werd aan David Nassy en zijn medestanders "als Patroon ofte Patroonen» vergund een kolonie op te richten op "het Eiland ofte Rivieren van "Cajana», mits blijvende op een zekeren afstand van de andere volksplanting aldaar. Hun werd bij art. III toegestaan «de Vrije «en alodiaale eigendom ten eeuwige dagen van de voorsz. Colonie "met de appendentien en de dependentien van dien», voor zoover zij die in vier jarentijds zouden hebben "bevolkt, bearbeid, «beheerd, aangewezen en gecultiveerd». Dientengevolge zouden zij daarover mogen "disponeeren voor altoos bij Testament, "Contract, verbintenis ofte anderszins, so men hier van zijne "vrije eigen Goederen vermag te doen, zonder dat nogthans "zodaanig Testament of Contract plaats» zou "hebben indien "de Colonie daar door van deezen Staat en Compagnie "zouden worden afgesneeden en aan andere Landen gebragt . De kolonie, waaraan bij art. IV hooge, middelbare en lage jurisdictie werd toegestaan, zou krachtens art. V door "David "Nassy en zijn medestanders bezeeten worden bij form van «leen, stellende ten dien einde sufficantelijk een Persoon ofte "meer Persoonen daar op het leen geconfereerd» zou worden "met betaaling van zekere Heergewaaden, ter waarde van zestig Dl. 70 . 
«Gulden»; blijvende, volgens art. VI, "niettemin de Souveraini«teit en de hooge Overigheid met al hetgeene daaraan dependeerd «aan hun Hoog Mogende en de Compagnie, voor zoo verre »dezelve bij het Octroy daar toe gerechtigd» was.

Een lange duur was aan deze kolonie niet beschoren. In 1664 werden de Joden met de Nederlanders door de Franschen uit Cayenne verdreven. $\mathrm{Zij}$ vestigden zich daarop in de destijds Engelsche kolonie Suriname, waar de Nederlanders hen drie jaren later zouden terugvinden. Hoewel Suriname eigenlijk nimmer rechtstreeks van de Compagnie afhankelijk is geweest, is het octrooi van 1659 er steeds als de grondslag van de rechten der Joden beschouwd. Wellicht heeft daartoe de omstandigheid medegewerkt, dat het, blijkens den aanhef, niet bij uitsluiting een vestiging in Cayenne had bedoeld, maar de mogelijkheid had geopend om zich desgewenscht op "andere plaatsen aan "de Wilde Kust van Westindien» neder te zetten.

Een nog grooter vrijheid ten aanzien van de plaats der voorgenomen volkplanting treffen wij aan in de uitgifte van een landstreek "op de Wilde Kust van America" aan Frederik Casimir graaf tot Hanau, die een Hoogduitsche kolonie wenschte op te richten en daarvoor den $18^{\text {den }}$ Juli 1669 een overeenkomst met de Compagnie trof (H. 216 vlg.). Bij art. II van die overeenkomst gaf de Compagnie "de voorsz. Landstreeke aan Zijne «Excellentie uit als een Leen of Feudum, met alle zijn Regaalen «en toebehooren, hooge, middelbare en lage Jurisdictie, zulks "dat zijn Excellentie aan de Compagnie in de name van de « Hoog Mogende Heeren Staten-Generaal in de voorsz. Colonie "op de wilde Kust door zijn Gemachtigde Homagie zo als alhier "geannexeert», zou "presteren, en vervolgens in den name als "boven, aldaar Vasal van de Compagnie zijn» zou, "zonder "desselfs prejuditie in Europa en het Roomsche Rijk». Krachtens art. IV zou Z.E. "de voorsz. Landen na zijn welbehagen en "believen mogen verdeelen, en geeven aan wien hem believen, "op zoodanige Conditie als hij best en geraaden dunken» zou, "en dienvolgende daar van Achter- of Onderleenen uitgeven "voor eeuwig en erfelijk of op termijn, met en zonder Juris"dictie na desselfs eigen goedvinden, des dat de voorsz. "Onderleenen of sub feudations aan de Compagnie bekend "gemaakt, en bij dezelve geconfirmeert» zouden worden "mits "betaalende voor Heergewaaden vijf honderd ponden Suiker, te 
«redimeeren met tien Ducaten». Belangrijk voor de rechtsverhouding was ten slotte nog art. XIV, volgens hetwelk de Compagnie gehouden zou zijn "neffens het eerste transport van dito colo"niers, beneffens den Gouverneur van zijn Excellentie of Ge"machtigde mede te zenden een of meer Gemachtigdens, om "na gebruik de Possessie aan zijn Excellentie of Gemachtigde "over te geven, en daar tegen wederom te ontfangen van de "volmachtigde van zijn Excellentie den Eed of Homagium.

"Het Homagium dat bij zijn Excellentie en desselfs Heren "gesubfeudeerde» zou worden "gepresteert» zou "hier in be"staan, dat zijn Excellentie, als mede de Heren gesubfeu"deerde respectivelijk de Landen in feudum uitgegeven niet en » zouden "vervreemden nog te alieneeren van de vereenigde Neder"landen en de Westindische Compagnie, en dat dezelve deeze "tegenswoordige Articulen onverbreekelijk» zouden "houden, "gelijk de Compagnie mede aan hare zijde dezelven onver«breekelijk» zou "presteeren *

Blijkens Hartsinck (222) had deze uitgifte op verzoek van eenige vorsten geen voortgang en werd een dergelijk ontwerp, eenigen tijd later door een zekeren Camerling ingediend, van de hand gewezen. In de werkelijkheid hebben deze bepalingen dus niet gegolden.

Het loont de moeite al deze Westindische leenen - volgens het, eigenlijk onjuiste, spraakgebruik worden hieronder de Zuidamerikaansche begrepen - nog eens in verband met elkander aan een beschouwing te onderwerpen. Aanvankelijk trad het feodale karakter der uitgiften weinig op den voorgrond. Zelfs nadat het leenstelsel in optima forma voor Nieuw-Nederland was aanvaard, ging men in West-Indië op den ouden voet door. Het weinige genoegen, dat men in Noord-Amerika van dat stelsel had beleefd, is daarop waarschijnlijk niet zonder invloed geweest. Misschien ook heeft de bekende naijver tusschen Zeeland en Amsterdam de navolging van hetgeen in Nieuw-Nederland geschiedde langen tijd tegengehouden. Maar de hoofdoorzaak zal wel gelegen zijn geweest in den handelsgeest van die dagen, die vooral van tropische koloniën groote winsten verwachtte. Wat in West-Indië gebeurde zal daarom aan de Compagnie meer ter harte zijn gegaan dan hetgeen in Noord-Amerika plaats greep. Een ver strekkende afstand van rechten was tusschen de keerkringen voor haar een veel belangrijker zaak dan in een 
gematigde luchtstreek. De oudste uitgiften in West-Indië bevatten dan ook geen voor het leenrecht kenmerkende bepalingen. De stichters van de volkplantingen heetten evenals in Nieuw-Nederland "patroon», maar bij deze aanwijzing bleef het. Zelfs waren de toegekende rechten aanvankelijk aan een bepaalden termijn gebonden. Neemt men de omschrijving van De Groot (Inl. II. XLI. 1) ${ }^{1}$ als maatstaf, dan zou dat zelfs in strijd zijn met het wezen van het leenrecht. Maar in dit opzicht is die omschrijving minder juist. Het kenmerk van leenrecht is volstrekt niet gelegen in den omvang, dus ook niet in den duur, maar alleen in den aard van de bevoegdheden des bezitters. Leenrecht is een verzakelijkt persoonlijk recht, hetwelk eigenlijk iedere willekeurige onroerende zaak tot voorwerp kan hebben. In de uitgifte aan graaf Hanau werd de mogelijkheid van tijdelijke leenen dan ook uitdrukkelijk erkend.

$\mathrm{Na}$ het verlies van Brazilië in 1654, waardoor de Compagnie voor goed haar macht en aanzien verloor, kwam er verandering in haar staatkunde ten opzichte van de Westindische kolonien. Wel werd voor de uitgifte van Tabago in 1655 nog het model van het octrooi voor St. Maarten gevolgd, maar dat wordt voldoende verklaard door het feit, dat beide eilanden in handen waren van dezelfde personen, t.w. de gebroeders Lampsins. Alle uitgiften na dien tijd hebben echter een onmiskenbaar feodale kleur. Steeds vindt men een nauwkeurige regeling van heergewaden, manschap en jurisdictie. Het hoogtepunt van feodaliteit werd bereikt in de uitgifte aan graaf Hanau, die o. a. niet meer den titel van patroon zou dragen, maar als "vasal» van de Compagnie werd aangeduid. Wellicht heeft toen de omstandigheid, dat men met een uiterst feodaal heerschap te doen had, de Compagnie in haar liefde voor het leenrecht nog versterkt.

De hier geschetste vooruitgang in de richting van de feodaliteit betrof niet alleen de jurisdictie, maar ook de rechten op den grond. Aan David Nassy c. s., die de kolonie - dus niet alleen de jurisdictie - bij wijze van leen zou bezitten, werd bovendien nog de vrije en allodiale eigendom van den grond toegezegd. Deze bepaling, in strijd met het beginsel der feodaliteit, ver-

1 Leenrecht is een erfelijke onsplisbare tocht op eens anders ontilbaar goed, met onderlinge verbintenisse van schut aan de eene zijde, en plicht van manschap en heergewaden aan de ander zijde. 
toonde veel overeenkomst met hetgeen destijds in Nieuw-Nederland voor de patroonschappen rechtens was. Bovendien kan zij in dit bijzondere geval wellicht verklaard worden in verband met vroegere Braziliaansche toestanden of met de eigenaardigheden van den Joodschen volksaard. Bij de latere uitgiften aan graaf Hanau (1669) en aan Van Pere (1678) treffen wij zulk een bepaling niet meer aan. Blijkbaar maakte de Compagnie van den nood een deugd. Door een zuivere toepassing van het leenrecht zocht zij tevens eenige vergoeding voor het daardoor veroorzaakte verlies van gezag. Die vergoeding bestond in de, zij het dan ook schoolsche, handhaving van haar eigendomsrecht op den grond, waarvan zij door den drang der omstandigheden vroeger zoo dikwijls tegen haar zin afstand had moeten doen.

Hoezeer de ontwikkeling van het leenrecht samenvalt met den achteruitgang van de Compagnie blijkt het duidelijkst uit twee gevallen, die tot dusver met stilzwijgen werden voorbijgegaan. Het eene heeft zich in Noord-, het andere in ZuidAmerika voorgedaan. Hun nouwe verwantschap liet niet toe ze van elkander los te maken. Hun zeer bijzondere aard rechtvaardigt een afzonderlijke behandeling.

Zooals reeds vroeger werd medegedeeld, was van Swaanendael, onze oudste vestiging aan de Zuidrivier of Delawarebaai, niet veel terecht gekomen. Later (1638) was daar of daaromtrent een Zweedsche kolonie gesticht door Petrus Minuit (Br. I. 291), die tevoren directeur van Nieuw-Nederland was geweest en voor zijn plannen tot ontwikkeling van dat land toen weinig medewerking had ondervonden. Deze kolonie had langen tijd haar onafhankelijkheid weten staande te houden, maar in 1655 was het aan den directeur-generaal Stuijvesant gelukt haar onder het gezag van de Compagnie terug te brengen. Dat de Compagnie, ondanks haar treurigen toestand, dit gunstige resultaat had kunnen bereiken was voornamelijk te danken geweest aan de stad Amsterdam, die de kosten van de expeditie had betaald. Kort daarna nam Amsterdam ook het bestuur van het nieuwe gebied voor zijn rekening door de jurisdictie daarover van de Compagnie in leen te nemen (Br. II. 201). Als stichters en coloniers van dat gebied, hetwelk voortaan als Nieuwer-Amstel bekend stond, werd aan Amsterdam door H. H. M. en de Compagnie toegestaan hooge, middelbare en lage jurisdictie «omme "te beter de gerequireerde authoriteit bij de haare te mainti- 
"neeren» (art. 2) ${ }^{\prime}$. Deze jurisdictie zou bezeten worden «bij «forma van Leen, stellende tot dien einde successievelijk een "persoon daarop het Leen geconfereert» zou worden "met be"taaling van zekere Heergewaden" (art. 3); blijvende niettemin "de Souverainiteit en hooge Overheid met alle hetgeene daar "aan dependeerd, aan hun Hoog Mogende en de Compagnie, "voor zo verre dezelve bij het Octroy daartoe gerechtigd" was (art. 4).

Meer bevatte de uitgifte, die bij een uitvoerig reglement werd uitgewerkt, niet. In het bijzonder treft ons de ontstentenis van eene bepaling nopens het recht op den grond. Zeer waarschijnlijk is het dat men ook de grond in de beleening begrepen heeft geacht. In ieder geval verbleef de allodiale eigendom daarvan aan de Compagnie, zooals duidelijk bleek uit hetgeen later plaats greep.

De kolonie Nieuwer-Amstel kostte aan Amsterdam veel geld: voortdurend moesten daarvoor aanzienlijke sommen beschikbaar worden gesteld. Dat deze offers niet voor een eigen kolonie werden gebracht, maar eigenlijk aan een gebied van de W. I. C. ten goede kwamen werd steeds sterker gevoeld. Amsterdam begon daarom op vermeerdering van rechten aan te dringen, maar de Compagnie had daarnaar weinig ooren. Op den duur echter kon de berooide W. I. C. aan den herhaalden aandrang van de machtige koopstad geen weerstand bieden. Den $12^{\text {den }}$ Februari 1663 kwam de verlangde regeling tot stand $(\mathrm{Br}$. II. 197 vlg). Daarbij werden alle eigendomsrechten op den grond in de kolonie aan Amsterdam afgestaan. Ook in andere opzichten werden de rechten van deze stad dusdanig uitgebreid, dat men na dien tijd moeilijk meer van een leenverband kon spreken. De leenheerlijke verplichting van "schut» verviel dan ook, hetgeen blijkt uit de bedongen overgave van het fort Christina aan de stad Amsterdam en de vervanging van de Compagniessoldaten aldaar door Stadstroepen. De weinige hoogheidsrechten, die de Compagnie, als vertegenwoordigster van de hooge overheid, daarna nog in naam bleef uitoefenen, vervielen toen het volgende jaar ons geheele Noordamerikaansche gebied in Engelsche handen overging.

1 Deze aanhalingen zijn niet ontleend aan Br., die alleen de Engelsche vertaling geeft, maar aan H., die de gelijkluidende uitgifte van Essequebo (zie hieronder) woordelijk mededeelt. 
Het voorbeeld ten aanzien van Nieuwer-Amstel gegeven werd een paar jaren later (1657) nagenoeg letterlijk nagevolgd voor Essequebo of Isekepe, zooals men toen veelal zeide. De rechtstreeks door de Compagnie bestuurde vestiging aldaar had weinig resultaten opgeleverd. Daarom had de Raad van XIX, die destijds al zijn aandacht voor het zooveel belangrijker Brazilië noodig had, in 1632 besloten haar op te geven. De Kamer van Zeeland had zich echter tegen dat besluit verzet en de kolonie op eigen gelegenheid aangehouden. Door den achteruitgang van de Compagnie werd deze taak echter op den duur voor haar te zwaar. $\mathrm{Na}$ het verlies van Brazilie bleek voortzetting niet langer mogelijk. Daarom werd het bestuur van Essequebo in 1657 overgegeven aan de Staten van Zeeland, maar gebrek aan eenstemmigheid in hun boezem noodzaakte hen het weder te laten varen. De drie Walchersche steden, Middelburg, Vlissingen en Vere, belastten er zich toen mede. Zij ontvingen van de Kamer Zeeland de jurisdictie over de kolonie in leen op voorwaarden, die om zoo te zeggen woordelijk overeenkwamen met die van de uitgifte van Nieuwer-Amstel aan Amsterdam (H. 838).

In 1666 werd Essequebo door de Engelschen veroverd, maar reeds in 1667 werden dezen door den commandeur van het naburige Berbice verdreven. De Zeeuwsche vlootvoogd Crijnssen, die in dat zelfde jaar tot ontzet van de koIonie verscheen, kon dan ook volstaan met haar over te nemen. Uit deze simpele feiten sproot een ingewikkeld rechtsgeschil voort, hetwelk thans alleen nog van belang is om te doen zien hoe weinig instemming het door de Compagnie vertegenwoordigde stelsel destijds meer genoot. Zeeland meende nl. uit die feiten zijn uitsluitenden eigendom van Essequebo te kunnen afleiden. Doordat de Engelschen de kolonie hadden veroverd zouden de rechten van de W. I. C. te niet zijn gegaan, terwijl het eigendomsrecht, althans het utile dominium van Zeeland ontstaan zou zijn als gevolg van de herovering door een Zeeuwsche vloot. De W. I. C., wier rechten op een octrooi van de Staten-Generaal berustten, beweerde van haar kant dat de vloot tot ontzet van Essequebo niet door Zeeland, maar door de Staten-Generaal was uitgezonden. Het feit dat Zeeuwsche schepen de opdracht hadden ten uitvoer gelegd was volgens haar een bloot toeval.

Hetgeen korten tijd later geschiedde maakte aan dit geschil een einde. Wellicht is daarop de omstandigheid van invloed 
geweest, dat ten aanzien van het in 1667 door Crijnssen veroverde Suriname een dergelijk rechtsgeschil was ontstaan tusschen Zeeland en de Generaliteit, hetwelk voorloopig onbeslist bleef en de feitelijke bezetting door Zeeland liet voortduren. Want toen de Walchersche steden, die zich na de ondervonden moeilijkheden van het bestuur der kolonie wilden ontlasten, haar in 1669 aan de Staten van Zeeland overdeden, bleken dezen aan Suriname genoeg te hebben. Althans droegen zij Essequebo in 1670 weder op aan de W. I. C. ter Kamer Zeeland. De leenroerigheid van deze kolonie eindigde hierdoor.

Het uitsluitend recht van de Kamer Zeeland verviel bij den ondergang van de eerste W. I. C. in 1674. Niettemin werden de gewone handelsbemoeiingen met, en het dagelijksch bestuur van Essequebo - van waaruit later (1746) Demerary gekoloniseerd zou worden - ook door de tweede Compagnie aan die kamer overgelaten.

Dat de W. I. C. die haar rechten aan den Staat ontleende, haar verplichtingen door middel van het leenrecht weder op den Staat - meer bepaald op zijn leden — afwentelde toonde zoo duidelijk haar onmacht aan, dat verandering in den toestand moeilijk kon uitblijven. Rechtstreeksch staatsbestuur met terzijdestelling van de Compagnie werd er door voorbereid. De medegedeelde oneenigheden tusschen Zeeland en de Compagnie over Essequebo waren reeds een aanwijzing voor de kentering in de openbare meening te dien opzichte. Toepassing vond het nieuwe stelsel het eerst in Suriname, dat jaren lang (tot 1682) onder het rechtstreeksche bestuur van Zeeland verbleef, omdat men het niet geheel eens kon worden over de voorwaarden om de kolonie "generaal te maken». Dit voorbeeld vond navolging. Toen de admiraals Evertsen en Binkes in 1673 Nieuw-Nederland heroverden, deden zij dat niet voor de zieltogende eerste W. I. C. maar voor de Staten-Generaal der Vereenigde Nederlanden. Na de oprichting van de tweede W. I. C. in 1674 ging men voorloopig op denzelfden voet door. De verovering van Cayenne door den reeds genoemden Binkes in 1676 - dat was dus onze vierde komst aldaar - en onze derde vestiging aan de Wiapoco onder Apricius en Tobiassen in het volgende jaar geschiedde eveneens namens den Staat. Ook Tabago kwam, zooals wij gezien hebben, in 1677 door aankoop onder het rechtstreeksch gezag van de Staten-Generaal. 
De meeste van deze staatskoloniën hadden intusschen een zeer kortstondig bestaan. Zeer spoedig werden zij door onze vijanden hernomen. Na den vrede van Nijmegen in 1678 hadden wij daarvan alleen Suriname over. Waarschijnlijk heeft deze omstandigheid er toe medegewerkt dat men het stelsel van rechtstreeksch staatsbestuur weder liet varen en weder algemeen gebruik ging maken van de tusschenkomst der tweede W. I. C., die langzamerhand een verandering van de stemming in haar voordeel had weten te verkrijgen. Immers deed Zeeland, hetwelk zich vroeger altijd tegen zulk een denkbeeld had verzet, in 1682 de kolonie Suriname aan de W. I. C. over voor den prijs van $f 260.000$. - .

Ten aanzien van de tevoren uitgegeven leenen kan men een soortgelijk verloop vaststellen. De meeste waren reeds gedurende het bestaan van de eerste W. I. C. geeindigd, sommige door het tenietgaan van de leenroerigheid zonder meer, de meeste evenwel door verlies aan den vijand. Alleen de beide leenen van de familie Van Pere bestonden nog bij het optreden van de tweede W. I. C. Nadat deze haar aanvankelijk betwiste leenheerlijke rechten in 1678 erkend had gezien, kon zij door aankoop het rechtstreeksch bestuur van St. Eustatius verkrijgen, ongeveer terzelfder tijd dat zij Suriname van Zeeland kocht. Het eenige patroonschap dat daarna overbleef was dat van Berbice. Daaraan kwam in 1712 een einde.

\section{Het Grondbezit.}

Het beginsel, dat de eigendom van den grond haar bleef toebehooren en de kolonisten daarop slechts een afgeleid recht konden hebben, werd door de Westindische Compagnie niet alleen toegepast bij de vestiging van patronaten, maar beheerschte ook den toestand van het grondbezit in de rechtstreeks door haar bestuurde gewesten.

Op de kust van Afrika was vestiging niet toegelaten. De vraag naar de rechtsverhouding tusschen de Compagnie en haar kolonisten ten opzichte van den grond had voor dat gebied dus geen belang.

Bij de verovering van Brazilië werd een reeds gezeten plantersbevolking aangetroffen. Tot haar geruststelling werden zoogenaamde Capitulatiën afgekondigd (Luzac I 323), waarbij aan 
de inwoners o. $\mathrm{m}$, het vrij bezit van hun goederen (sub $4^{\circ}$ ) werd toegezegd. Van eigendom werd niet gesproken. Hunnerzijds moesten zij de tienden van tien ten honderd van hun voortbrengsels afstaan (sub $3^{\circ}$ ). Ook de toegezegde bescherming (sub $2^{\circ}$ ) en vrijdom van gedwongen krijgsdienst (sub $8^{\circ}$ ), alsmede de eed, waarvan sub $7^{\circ}$ beperking tot getrouwheid en verzekering werd toegelaten, wijzen op het feodale karakter van de verhouding.

Ten aanzien van Essequebo, dat, behoudens een kortstondig tusschenbestuur door de drie Walchersche steden, steeds tot het rechtstreeksch gebied van de Compagnie heeft behoord, kon schr. dezes tot nog toe geen gegevens vinden. Alleen vermeldt Hartsinck (268) de voorwaarden, waarop in 1745 door de Kamer Zeeland vestiging werd toegelaten aan de toen nog onbewoonde Demeraryrivier. De desbetreffende resolutie van 18 October sprak van vergunning tot het aanleggen van plantages en van het verleenen van gronden; van den eigendom werd met geen enkel woord gerept.

Voor den rechtstoestand van het grondbezit in Nieuw-Nederland zijn de drie reglementen van Vrijheden en Exemptien, die aldaar achtereenvolgens gegolden hebben, de belangrijkste kenbronnen. Die van 1629 en 1640 hadden voornamelijk de vestiging van patroonschappen ten doel. Van particuliere kolonisten werd daarin niet veel gezegd. Toch bevatte het reglement van 1629 reeds de bepaling, dat zij bezit zouden kunnen nemen van zooveel land als zij in staat zouden zijn in cultuur te brengen en dat zij daarvan den vollen eigendom zouden genieten (art. 21, Br. II 553). Het reglement van 1640 (Br. I. 119) omschrijft hun rechten zelfs nog iets nauwkeuriger. Het bepaalde dat de gouverneur hun den eigendom zou kunnen toekennen van 100 Rijnlandsche morgens grond, onderling aan elkander grenzende. Hoewel in beide gevallen van eigendom werd gesproken, is het toch zeer de vraag of daarmede wel bedoeld werd hetgeen men zou verwachten. Het onderscheid tusschen eigendom en leenrecht was van schoolschen aard en had voor de practijk niet veel belang. Het kan geen nut hebben gehad de aandacht van de kolonisten, die als regel wel geen rechtsgeleerden geweest zullen zijn, te vestigen op een fijn verschil van theoretischen aard, dat alleen ten doel had aan de Compagnie eenige zelfvoldoening te schenken. Men zal het meest uitgebreide recht 
op den grond daarom gemakshalve met eigendom hebben aangeduid, zonder verder over den aard van dat recht te beslissen. Dat een feodale eigendom, geen contradictio in terminis meer was bewees het Engelsche recht, volgens hetwelk de kolonie Suriname in 1662 tegelijk in vollen eigendom en als een vrij afhankelijk leen (in Free and Comon soccage) kon worden gegeven (H. 522 vlg.). Ook de geschiedenis van het leenrecht ten onzent bewijst dat het zich allengs vervormde tot een van regalia voorzienen eigendom, die, na de afschaffing van de heerlijke rechten, als gewone eigendom zou blijven voortbestaan.

Behalve het algemeen beginsel van de grondpolitiek der Compagnie zijn er drie zeer sterke aanwijzingen voor de juistheid van hetgeen hierboven verondersteld werd. Vooreerst blijkt uit de verleibrieven van de patronaten, die krachtens het reglement van 1629 werden gesticht (Br. I. 43 en 44), dat een afstand van den eigendom door de Compagnie vereenigbaar werd geacht met voorbehoud van een hooger recht. Deze zaak kwam reeds in het vorige hoofdstuk ter sprake en behoeft thans geen nadere bespreking. De tweede aanwijzing kan geput worden uit het reglement van 1640. Onder aandrang van de Staten-Generaal had de Compagnie daarbij aan de patroons den allodialen eigendom van den grond moeten toezeggen. En nu is het merkwaardig dat de bijvoeging: "allodiaal» wordt gemist in de omschrijving van het recht der zelfstandige kolonisten. Dit geeft vooral te denken - en zoo komen wij tevens tot de derde aanwijzing wanneer men het reglement van 1640 met dat van 1650 vergelijkt.

Daar de patroonschappen de kolonisatie niet blijvend hadden kunnen bevorderen en bovendien aan de Compagnie steeds groote moeilijkheden hadden berokkend, geraakten zij bij het reglement van 1650 een weinig op den achtergrond. Hoofddoel van de nieuwe regeling ( $\mathrm{Br}$. I. 401) was de vestiging van zelfstandige kolonisten. Desniettegenstaande werd hun eigendomsrecht op den grond uitgesloten. $\mathrm{Zij}$ zouden zooveel land kunnen bekomen als zij in staat zouden zijn te bebouwen, maar hun recht werd uitdrukkelijk omschreven als erfpacht of leen. Hadden zij behoefte aan weiland, dan zou hun dat worden aangewezen voorzoover de omstandigheden dat zouden veroorloven. Van eenig recht op dien weidegrond werd dus niet gewaagd.

De besproken bepalingen betroffen niet het eiland Manhattan, hetwelk bij de genoemde reglementen steeds met zoo veel 
woorden door de Compagnie aan zich was voorbehouden. Aanvankelijk bevorderde de Compagnie de kolonisatie aldaar door op eigen kosten boeren te doen overkomen (Br. I. 371). Dezen ontvingen dan een huis en het vereischte gereedschap alsmede het vruchtgebruik van het noodige vee. $\mathrm{Z}_{\mathrm{ij}}$ werden evenwel geen eigenaar van hun boerderij of bouwerij, zooals men zeide, maar zij kregen die voor 6 jaren in huur tegen een pacht van f 100.- en 80 pond boter. Later werden deze regelen door andere vervangen. De inhoud daarvan blijkt echter niet uit Brodhead. Alleen de medegedeelde Instructie van DirecteurenGeneraal en Raden van Nieuw-Nederland van 1646 (Br. I. 161) bevat nog iets daaromtrent. Dezen moesten namelijk trachten te bewerken dat de kolonisten zich in dorpen vestigden, en zulks in de eerste plaats op het eiland Manhattan, waar zij hun zooveel land zouden toemeten, als zij in staat zouden zijn te bebouwen. Aangenomen mag intusschen wel worden dat de Compagnie op haar eigen eiland Manhattan ten aanzien van den grondeigendom niet viijgeviger is geweest dan in het gverige deel van Nieuw-Nederland.

Tot goed verstand van het grondbezit op Curafao dient men twee zaken in het oog te houden. Het eiland werd in 1646 onder het bestuur van Stuyvesant met Nieuw-Nederland vereenigd en bleef daarmede verbonden tot aan het verlies van ons Noordamerikaansch gebied (1664). Bij de samenvoeging bestond er nog geen volkplanting. Blijkens Brodhead dagteekenen plannen tot het bevolken van Curaçao eerst van 1650 (zie ook Ham. I. D. 43). De werkelijke kolonisatie is nog jonger.

Uit een en ander laat zich begrijpen dat het reglement van Vrijheden en Exemptien, hetwelk in 1650 voor Nieuw-Nederland werd vastgesteld, ook voor de rechten van de Curaçaosche kolonisten van belang geweest is. Welke invloed er van is uitgegaan, heeft schr. dezes niet kunnen vaststellen. Brodhead heeft uit den aard der zaak geen Curaçaosche documenten uitgegeven en Hamelberg, die een gedocumenteerde geschiedenis van Curaçao leverde, heeft aan het hier bedoelde verband geen aandacht geschonken. Misschien heeft men het reglement als voorbeeld gebruikt voor een zelfstandige Curaçaosche regeling; wellicht hebben de bepalingen er van op het eiland rechtstreeksch toepassing gevonden. Voor de laatste veronderstelling pleit dat Hamelberg, die aan den toestand van het grondbezit de noodige aandacht 
wijdde, over dat onderwerp geen enkele regeling mededeelt. Hoe dat ook zij, verband moet er geweest zijn. De omstandigheid, dat de Compagnie den eigendom van den grond niet aan de kolonisten overdroeg en zich verzette tegen hun vermeende aanspraken daarop, is daarvoor reeds een aanwijzing. Maar sterk is zij niet. Deze gedragslijn toch berustte op een beginsel, dat den grondslag vormde van de staatkunde der Compagnie en derhalve op haar gansche gebied tot uitdrukking moest komen. Meer bewijskracht heeft het feit dat aan de kolonisten op Curaçao de bevoegdheid werd verleend om hun vee te weiden buiten de grenzen van de hun toegewezen landen. Deze bevoegdheid was geheel overeenkomstig de desbetreffende bepaling van het Nieuwnederlandsche reglement van 1650 .

Daar het weiderecht op Curaçao tot op het huidige oogenblik een brandend vraagstuk is gebleven, is het noodig daarbij iets langer stil te staan. Tot dusver werd de oorsprong van dat recht nimmer verklaard als boven plaats had. De ambtelijke opvatting is anders. Die opvatting is belichaamd in het rapport van de door den gouverneur De Jong van Beek en Donk benoemde Koloniale Commissie tot onderzoek van de toestanden in het groote landbouwbedrijf op Curaçao, d.d. 9 Juni 1910, hetwelk als bijlage D werd toegevoegd aan het Koloniaal Verslag van 1910. "Het blijkt uit een in 1850 naar de koopbrieven * der plantages opgemaakten legger van verleende privilegiën "tot het weiden van vee op de publieke gronden" - zoo zegt de Commissie op blz. 4 van haar verslag - "dat tot 1680 aan "geen enkele plantage het weiderecht was toegekend.... De "verkrijging van het recht, waarop de planters zich thans be"roepen, is dan ook van lateren oorsprong". Was deze bewering juist, dan zou het weiderecht ongeveer 20 jaren - het eerste bekende privilegie werd in 1684 aan de plantage Puerto Marie verleend - na het verlies van Nieuw-Nederland zijn ontstaan. Een verband met een reglement dat 34 jaren te voren was ingevoerd en reeds 20 jaren buiten werking was zou dan zeker niet zeer waarschijnlijk zijn. Maar de opvatting van de commissie kan den toets der critiek niet doorstaan. De door den gouverneur Jhr. I. J. Rammelman Elsevier Jr. den $4^{\text {den }}$ Juni 1850 onder $\mathrm{n}^{\circ} .223$ genomen beschikking, krachtens welke de bovenbedoelde legger werd opgemaakt, overweegt uitdrukkelijk «dat de bewijzen "daarvan(d.w.z. van die privilegiën) slechts kunnen geput worden uit 
"de koopbrieven der plantagiën, vermits een boek van privilegiën, "hetwelk aanvankelijk heeft bestaan, uitwijzens de uit hetzelfde "gemaakte extracten, welke aan sommige koopbrieven zijn ge"annexeerd, niet in het archief der Kolonie aanwezig is." Het feit dat men geen andere privilegiën heeft kunnen vinden dan van 1684 bewijst dus niet heel veel. Bovendien is de plaats uit Hamelberg (I, 86, vlg.), waarop de Commissie blijkbaar haar meening grondt en die onmiddellijk te voren woordelijk door haar wordt aangehaald, juist een bewijs tegen haar stelling. Schr. dezes kan dat niet beter duidelijk maken dan door ook zijnerzijds het bewuste gedeelte van Hamelberg af te schrijven. "Er waren andere (dan haar eigen) plantages, die zij (de "Compagnie) in huur had uitgegeven en bovendien maakte zij "aanspraak op vele gronden, door particulieren in bezit gehouden. "Volgens haar octrooi behoorden haar alle gronden van het "eiland zonder uitzondering en oorspronkelijk had de Compagnie "aan particulieren slechts zooveel grond afgestaan, als zij voor "hun onderhoud en dat hunner gezinnen noodig hadden. Zulke "gronden moesten worden omheind om het losloopende vee "der Compagnie er buiten te houden en aan de bezitters werd "het veelal vergund het voor hen en hunne gezinnen benoodigd "vee te laten weiden op de Compagnie's "savanen», d.w.z. de "gronden, niet door de Compagnie's plantages ingenomen. Ook "werd deze vergunning tot het houden van vee ter voorziening "in eigen levensbehoeften wel gegeven zonder gelijktijdigen afstand "van terrein, doch in geen van beide gevallen mocht van dit "vee worden verkocht: den veehandel hield de Compagnie aan "zich. Maar in den loop der jaren hadden verscheidene particu"lieren veel meer grond omheind of «ingezerkt» (zooals men " het toen noemde), dan hun oorspronkelijk was toegestaan, "terwijl anderen, alleen de vergunning hebbende verkregen om "hun vee te laten weiden op de Compagnie's savanen, gedeelten "daarvan hadden doen inzerken om hun vee bij elkaar te houden "en die terreinen als hun eigendom beschouwden. Dit nu had "nooit in de bedoeling der Compagnie gelegen en in 1680 "kwam zij met nadruk tegen dit gemaakte misbruik op, "aan Van Liebergen berichtende, dat de handel in vee en "producten uitsluitend aan haar toekwam en de gronden aan "de ingezetenen niet in eigendom, maar hoogstens in concessie "waren afgestaan om te dienen voor hun eigen onderhoud en 
"niets meer. Aan Van Liebergen werd daarom gelast alles "op den ouden voet te herstellen; het aantal groot en klein vee, "dat een ieder zou mogen houden, opnieuw vast te stellen "na de "proportie van ijders gegoetheijt»; een boete te bepalen voor «elk beest, dat meer werd gehouden, en de putten, waarvan "er ook eenige door particulieren met het er om liggende «terrein waren ingezerkt, weder te openen».

Uit het bovenstaande blijkt zonneklaar dat er vóór 1680 weiderechten moeten zijn verleend. Anders had de directeur Van Liebergen in dat jaar niet de opdracht kunnen ontvangen, het daarvan gemaakte misbruik te niet te doen. Zooals reeds gezegd werd, is het niet onwaarschijnlijk dat zij uit den tijd van Stuyvesant dagteekenen, maar de gegevens om dat met volkomen zekerheid te zeggen ontbreken. In ieder geval zal het aanbeveling verdienen die rechten uit dit oogpunt nog eens aan een nader onderzoek te onderwerpen. Mocht bij dat onderzoek de juistheid van de gemaakte onderstelling blijken, dan zou het door het Koloniaal Bestuur staande gehouden recht, om den publieken weidegrond voor den kleinen landbouw uit te geven, een onbetwistbaren grondslag bekomen. Immers maakte de omschrijving van het weiderecht in het Nieuwnederlandsche reglement van 1650 dat recht van de omstandigheden afhankelijk.

Maar het wordt tijd om van het bijkomstige weiderecht naar de hoofdzaak terug te keeren. Zooals uit de aangehaalde plaats van Hamelberg blijkt, hield de Compagnie ook op Curaçao vast aan haar uitsluitend eigendomsrecht op den grond. Evenals in Nieuw-Nederland werden er aanvankelijk gronden in pacht gegeven, maar deze wijze van uitgifte schijnt reeds vrij spoedig door een andere vervangen te zijn. Voor de verpachting kwam een "concessie» in de plaats. Waarschijnlijk zal men die concessies wel in oorkonden hebben belichaamd, maar een voorbeeld van zulk een stuk is door schr. nergens aangetroffen. De omvang van het uit de concessie geboren recht moet uiteengeloopen hebben. Blijkens Hamelberg (I. 87 noot 4) werd in 1696 aan den commissaris Gerard Luls een stukje grond afgestaan, hetwelk bij zijn dooa of zijn vertrek weder aan de Compagnie zou vervallen. Als regel echter zal men duurzamer rechten hebben toegekend. anders hadden zij niet zoo spoedig met eigendom verward kunnen zijn. Blijkens de aangehaalde plaats van Hamelberg matigden de kolonisten zich vóór 1680 reeds 
eigendomsrechten op de Compagniesgronden aan, terwijl de bovenbesproken legger van privilegiën melding maakt van koopbrieven uit het jaar 1693 reeds. Het verzet van de Compagnie daartegen gaf niet veel. Van Liebergen bracht van de hem gedane - in de aanhaling van Hamelberg genoemde - opdracht weinig terecht (Ham. I. 89). Zijn opvolgers deden in het geheel niets. Eerder nog werkten zij de bevelen van de bewindhebbers tegen door, in strijd met hun uitdrukkelijke instructie, Compagniesgronden te verkoopen. In 1702 herhaalden de Bewindhebbers hun bevel (Ham. I. 90), eveneens zonder gevolg. "Het usur"peeren der gronden toch», zoo zegt Hamelberg (I. 90), "dag"teekende niet van enkele, doch van vele jaren her; de meeste "van zulke onrechtmatig weggegeven of in bezit genomen "gronden waren reeds in andere handen - ktot zelfs in de "vierde hand" - overgegaan; velen der usurpateurs waren al «lang van het eiland weg en er was niet één factoor, die de «juiste grenzen der oorspronkelijk afgestane, kleine stukken "grond kon aanwijzen. Gouverneur en raden achtten het dan "ook "gants ondoenlijk» de geusurpeerde gronden weer aan de "Compagnie terug te geven en bij zoo afdoend advies legden "bewindhebberen zich eindelijk neer». $Z_{i j}$ stelden zich zooveel mogelijk schadeloos door het heffen van een belasting op de geusurpeerde gronden, die in 1715 werd ingevoerd.

Feitelijk was daardoor het eigendomsrecht van de planters door de Compagnie erkend. Maar dat de in het stelsel der Compagnie geslagen wonde bleef schrijnen blijkt wel uit het feit dat nog in 1764 in de instructie van den gouverneur Rodier de la Brugère (Ham. I, D. 102) over de usurpatien werd geklaagd. "En alzoo, in vroege tijden, is bevonden", zoo zeide namelijk art. XX «dat vele Gronden en Landen, bekwaem tot "de Culture, aen Particulieren zijn uitgegeven, en alzoo de "Compagnie daarvan is ontzet geworden, zo zal hij Directeur "geenzins vermogen eenige Gronden of Landen, om onder "culture gebragt te worden, aen Particulieren uit te geven, om "wat reden of oorzaek het zoude mogen zijn, en zal hij Direc"teur zijn gehouden, in gevalle door Particulieren aen hem "verzoek wordt gedaen, om eenige onbebouwde Landerijen te "cultiveren en van de Compagnie te huuren, daer van met de "eerste gelegenheid, aen de Vergadering van Tienen kennisse "te geven, en zijne consideratien deswegens te communiceeren, 
"en zal hij niet vermogen eenige Erven van de Compagnie, "om daer op Huisen of eenige andere gebouwen te zetten, aen «Particulieren uit te geven, zonder daer van bevorens aen de "Vergadering van Tienen kennisse te hebben gegeven, en per"missie van de zelve bekomen".

Uit dit artikel blijkt tevens hoe de Compagnie in lateren tijd de uitgifte van grond geregeld had. Van toekenning van eigendom wilde zij ook in 1764 niet weten. Afgezien van het niet nader bepaalde recht, dat zij voor perceelen bouwgrond in uitzicht stelde, liet zij de uitgifte alleen toe in den vorm van een pachtovereenkomst en dat nog alleen na de bijzondere goedkeuring van de bewindhebbers.

Naar aanleiding van deze regeling doen zich verschillende vragen op. Was zij in het jaar 1764 nieuw of had zij ook reeds vóór de instructie van den directeur Rodier gegolden? Is zij tot den ondergang van de W. I. C. blijven gelden of werd zij reeds eerder door een andere vervangen? Is zij tijdens haar duur steeds nageleefd of is men er dikwijls van afgeweken, evenals men vóór 1715 de geboden der Compagnie op dit stuk zoo vaak overtreden had? Op al deze vragen blijft Hamelberg ons het antwoord schuldig. Een afdoende oplossing zal zonder een nader bronnenonderzoek waarschijnlijk niet te geven zijn; want met de gegevens, die in het reeds genoemde rapport nopens de toestanden in het groote landbouwbedrijf voorkomen, moet men uiterst voorzichtig zijn.

In dat verslag komt op blz. 8 een staat voor "aantoonende "den tijd van verkoop der plantages op Curaçao door het plaatselijk «bestuur en de wijze harer verkrijging van het weiderecht naar «tijdorde opgemaakt volgens den legger van verleende privilegiën "tot het houden van vee op publieke gronden op Curaçao "(Gouvernementsbeschikking 4 Juni 1850, $\left.\mathrm{N}^{\circ} 223\right)$ )" Blijkens dezen staat zouden van 1693 af bijna voortdurend plantages door het plaatselijk bestuur zijn verkocht. Waarschijnlijk echter heeft de Commissie ten onrechte den eersten koopbrief van een plantage met de uitgifte er van vereenzelvigd.

De Commissie, die geen oorspronkelijk werk leverde maar den legger van 1850 omwerkte, zegt dat de eerste koopbrieven verkoop door het plaatselijk bestuur betroffen, maar in den legger zelf vindt men daarvan niets. In dat stuk heeft men aanteekening gehouden van de oudste bekende oorkonden de plantages beDl. 70 . 
treffende en, voorzoover zij koopcontracten inhielden, die met "eerste koopbrief» aangeduid. Maar dat beteekent natuurlijk niet de onmogelijkheid van vroegere verkoopen. Dat die er in vele gevallen geweest moeten zijn blijkt bovendien duidelijk, zoodra men staat en legger wat nauwkeuriger beschouwt. Een plantage als Mount Pleasant of Mal Pais zou bij de opvatting der Commissie verschillende malen zijn uitgegeven; maar, daar zulks niet tot de volstrekte onmogelijkheden behoort, is dat niet meer dan een kleine aanwijzing. Ongeveer dezelfde kracht heeft de bij het standpunt der Commissie noodzakelijke gevolgtrekking, dat er aan plantages dikwijls weiderecht werd verleend vóórdat zij zelf waren uitgegeven. Ook dat laat zich nog denken: het weiderecht kan bijv. verleend zijn geweest aan een verhuurde plantage, die eerst later werd verkocht. Onwaarschijnlijk echter is het dat plantages als Klein St. Kruis en Klein St. Martha uitgegeven zouden zijn vóór de groote plantages van dien naam, want dat zou geheel in strijd zijn met den gewonen loop der dingen. Een bepaalde ongerijmdheid ten slotte is dat er volgens den staat der Commissie eerst in 1693 grond uitgegeven zou zijn, terwijl wij boven zagen dat de uitgifte van grond in 1680 reeds een geschiedenis had.

Geeft de legger ons dus geen uitsluitsel op de vraag of de Compagnie na 1715 nog gronden in eigendom uitgaf, wel blijkt er uit dat in 1796 dergelijke uitgiften hebben plaats gehad (Oostpunt en de Duivelsklip). Maar toen was de W. I. C. reeds eenige jaren ter ziele en met haar de feodale opvattingen van het grondrecht, die, voorzoover Curaçao betrof, reeds lang niet meer met den werkelijken toestand overeenkwamen.

Anders was het op de onderhoorige eilanden Aruba en Bonaire waar het leenrecht na den ondergang der W. I. C., ja zelfs tot ver in de $19^{\text {de }}$ eeuw stand hield. De Compagnie was daar gelukkiger geweest in het handhaven van haar eigendomsrecht op den grond. Langen tijd had zij de kolonisatie aldaar geheel weten te beletten en de vergunningen tot vestiging, die later door haar werden verleend, waren niet talrijk genoeg geweest om den toestand tegen haar zin te kunnen doen veranderen. Tot aan het eind van haar bestaan in 1791 bleef zij in staat het door haar toegekende leenrecht in zijn zuiveren vorm te handhaven en de Staat, die haar toen in den eigendom van den grond opvolgde, bracht voorloopig geen verandering in hetgeen hij aantrof. Art. 2 van de verordening van 31 December 1823 
(herdr. bund. $\mathrm{N}^{\circ}$ 66) kon dan ook nog bepalen dat het geheele eiland Bonaire als een Gouvernementsplantage werd beschouwd. En, hoewel Aruba niet als zoodanig gold, behoorde ook alle grond op dat eiland destijds nog tot het domein.

Hamelberg geeft in I. D. $\mathrm{N}^{\circ} .81$ den tekst van een eed, die in 1754 door een zekeren M. van S. Levy Maduro moest worden afgelegd ter verkrijging van grond op Aruba. Reeds het feit dat een eed gevorderd werd is kenmerkend voor het leenrecht; want de manschap of hulde, die de leenman verschuldigd was, bestond in een eed, waardoor hij zich verbond den heer getrouw te zijn, deszelfs voordeel te zoeken, hem ten beste te raden te helpen en bij te staan, zijn achterdeel - d. i. nadeel - te weren en te ontdekken 't geen strekken zoude mogen tot zijn schade (De Groot Inl. II, 41, 40). Al deze verplichtingen vindt men terug in den eed van Maduro, die moest zweren dat hij zich gedragen zou als een getrouw ingezetene, den Commandeur in alles zou gehoorzamen (trouzw) en met en benevens de andere bewoners der Edele Compagnie's werken zou helpen doen en de waterputten zou helpen schoonmaken (hulp en bijstand); dat hij in geenerlei maniere eenige negotie zou doen en aan niemand iets verkoopen of van vreemdelingen iets inkoopen ('s Heeren voordeel zoeken en achterdeel weren) en dat hij, indien hem iets dergelijks voorkwam door anderen gedaan, hij zulks aanstonds aan den Commandeur zou waarschuwen en insgelijks als hij iets zou te weten komen dat iemand iets tegen het eiland zou willen ondernemen (Raad en ontdekking van 't geen zou strekken tot 's Heeren schade). Wijders bevatte het eedsformulier de uitdrukkelijke erkenning van het recht der Compagnie, die den grond slechts precario had vergund; voorts een, blijkbaar ingelascht, verbod om ongeoorloofde veekoralen te houden, hetwelk verder onbesproken kan blijven, en ten slotte de regeling van het tenietgaan van Maduro's recht. Uit deze laatste regeling blijkt dat het leen een zoogenaamd "recht» of "kwaad" leen was, dat niet door opdracht of uiterste-wilsbeschikking aan derden kon overgaan. Het verviel door het uitsterven van de nakomelingen des begiftigde of «bloedsgebrek», zooals De Groot het noemt. Ook door "verbeurte» - het woord is van S. v. Leeuwen, De Groot spreekt in dit verband minder juist van kontrouw of smaad „ - kon het recht verloren gaan. Maduro moest namelijk zweren zijn verplichtingen stipt te zullen nakomen. Verzaakte 
hij ze, dan zou het land hem ontnomen en hij zelf van het eiland verzonden worden. In het te niet gaan van het recht was dus geheel overeenkomstig de regelen van het leenrecht voorzien.

Zooals reeds werd medegedeeld heeft het feodaal karakter van het grondrecht op Bonaire en Aruba tot in de $19^{\circ}$ eeuw stand gehouden. De rechthebbende op den grond werd "concessionaris" of ook wel "leenhouder» genoemd. In 1823 werd bij de reglementen van administratie en bestuur op die eilanden (Herdr. bund. $\mathrm{N}^{\text {os }}$. 66 en 67) bepaald dat de gronden, door de ingezetenen bij vergunning bezeten, aan hen in eigendom konden worden overgedragen tegen betaling van het gewone recht op den verkoop van vast goed. De uitgifte in concessie werd nader geregeld in 1829. Toen werd o.a. bepaald dat de concessionarissen het op hun grond gevonden goud aan het Gouvernement moesten afstaan, dat hun van $\frac{2}{3}$ de waarde zou uitkeeren, en dat het concessierecht niet hooger zou gesteld worden dan noodig was om de kosten van het toezicht te bestrijden.

Bij Koninklijk besluit van 16 September $1841, \mathrm{~N}^{\circ} 71$, werden de laatste sporen van het leenrecht uitgewischt en, ook voor de toekomst, door eigendom vervangen. Het recht op de mijnen werd echter uitdrukkelijk door de Overheid aan zich voorbehouden (zie ook publ. van 1 Juni 1842, herdr. bund. $\mathrm{N}^{\circ} 244$ ), terwijl het recht op het van ouds aan het Gouvernement toekomende verfhout reeds te voren (Publ. 30/31 Aug. 1839, herdr. bund. $\mathrm{N}^{\circ} 227$ ) voorbehouden was. Wonderlijk genoeg schijnt het zoo juist genoemde Koninklijk besluit door den samensteller van den herdrukten bundel der publicatiebladen als van voorbijgaand belang te zijn beschouwd. In die verzameling komt het althans niet voor.

De genoemde regelingen hadden alleen betrekking op Aruba. Op Bonaire was van de door het reglement van 1823 mogelijk gemaakte overdracht van grond weinig terecht gekomen. Het optreden van den baron Van Raders als gezaghebber (18:36), die die gouvernementscultures in de kolonie invoerde en voornamelijk Bonaire tot het terrein van zijn proefnemingen uitkoos, had daarop grooten invloed gehad. Het eiland was een gouvernementsplantage gebleven. Eerst na de opheffing van de gouvernementscultures kwam aan dien toestand een einde. In 1867 werd het eiland in groote kavelingen verkocht en in 1870 volgde den verkoop van de gouvernements-zoutpannen. Dien- 
tengevolge bestaat de grondeigendom op Bonaire nog steeds uit weinige, zeer uitgestrekte perceelen.

Over de geschiedenis van het grondbezit op de bovenwindsche eilanden St. Eustatius, Saba en St. Maarten heeft schr. dezes geen bijzonderheden kunnen vinden. Zooals werd medegedeeld stonden deze eilanden aanvankelijk onder het patronaat van de families Van Pere, Van Rhee en Lampsins. Destijds moet het gansche grondstelsel dus een feodaal karakter gehad hebben; want de patroons, die zelf slechts een feodaal recht bezaten, konden uitteraard geen allodiale rechten vestigen. Later - ook dat werd reeds medegedeeld - kwamen deze eilanden onder het rechtstreeksch bestuur der Compagnie, die haar uitsluitend recht op den grond ook daar wel zal hebben staande gehouden. Waarschijnlijk hebben de toestanden zich er toen ontwikkeld als op het eiland Curaçao. In 1737 toch klaagde de commandeur van de kolonie St. Eustatius, waartoe de drie eilanden behoorden, dat alle ingezetenen maar hadden getracht Compagniesgrond aan zich te trekken voor zich zelf en hun vrienden, waardoor de Compagnie haar land was kwijt geraakt. Land om te vergeven was er toen al niet meer. Deze bijzonderheid werd aan schr. medegedeeld door den gezaghebber van St. Eustatius, den heer G. J. van Grol, die in den loop van zijn bestuur aanteekening hield van verschillende feiten, het eiland betreffende, waarvan hij uit oude stukken kennis kreeg, maar die over de geschiedenis van den grondeigendom verder nooit iets was tegengekomen.

Ten slotte nog een enkel woord over Suriname, dat wel is waar nimmer onder het gezag van de Westindische Compagnie heeft gestaan, maar toch middellijk eenigen invloed van haar leenstelsel heeft ondervonden. In den aanvang was deze kolonie, zooals wij zagen, het voorwerp van een vrij schoolsch geschil tusschen de provincie Zeeland en de Staten-Generaal (H. 599). Zeeland maakte aanspraak op den eigendom van Suriname omdat de verovering van dat land in 1667 door hun vlootvoogd Crijnssen was geschied. De Staten-Generaal beweerden daarentegen dat zij de kosten van den tocht naar West-Indië hadden gedragen en dat de veroveringen dus ook te hunnen voordeele moesten komen. Hangende dit geschil bleef Zeeland, dat zich het gezag had aangematigd, in het bezit daarvan.

Deze toestand duurde tot 1682 . Wel had Zeeland reeds in 1672 aangeboden de kolonie "generaal te maken», maar men 
was het ten slotte over de voorwaarden niet eens kunnen worden, zoodat het plan mislukt was. Eén van de door Zeeland gestelde voorwaarden was geweest, dat de Westindische Compagnie, die destijds in het diepste verval was en zich het algemeene wantrouwen op den hals had gehaald, buiten het bestuur zou blijven. Korten tijd later (1674) was zij ten ondergegaan. Haar opvolgster, de $2^{\text {de }}$ W. I. C., had langzamerhand getracht het vertrouwen te herwinnen en zij was daarin tot op zekere hoogte ook geslaagd. Het mislukken van de koloniën, die men onder staatsbestuur had gesteld, had daartoe waarschijnlijk medegewerkt. In ieder geval was de openbare meening in 1682 weder zoover te haren gunste omgeslagen, dat zij Suriname, waarvan Zeeland zich toen wenschte te ontdoen, voor $\mathrm{f} 260.000$. - van die provincie kon koopen. Maar sterk stond zij toch nog niet. Den last van het bestuur der kolonie dorst zij niet op zich nemen. $\mathrm{Zij}$ bracht haar daarom in 1683 in een vennootschap, de Societeit van Suriname, waarin zij zelf voor $\frac{1}{3}$ aandeelhoudster bleef.

De omstandigheid, dat Suriname nimmer tot het gebied van de W. I. C. heeft behoord, heeft op de ontwikkeling van het grondbezit aldaar haar stempel gedrukt. De uit het octrooi der W. I. C. afgeleide leerstellingen behoefden er niet in toepassing gebracht te worden. Men schijnt dan ook nimmer eenig bezwaar gezien te hebben in het verleenen van allodialen eigendom. Wellicht heeft men, om die tegenstelling beter te doen uitkomen, op de allodialiteit van de toegekende rechten zelfs eenigen nadruk gelegd.

Blijkens te mijner beschikking gestelde aanteekeningen uit het domeinarchief te Paramaribo werd reeds in 1669 (22 Mei) en 1686 ( 7 November) vergund en gepermitteerd om gronden op te nemen en in volkomen of vrijen eigendom te bezitten. De oudste bekende grondbrief is die van 100 akkers land, op 12 September 1691 door den gouverneur Van Scharphuisen verleend aan de Joodsche natie, luidende:

"Jan van Scharphuisen, Gouver-Generaal van Suriname, "rivieren en districten van dien,

»Permitteeren en vergunnen mits deesen in allodiaalen eigen"dom en erffelijke besittinge aan de Joodsche natie tot gebruik "van haare sinagogue, begraafplaats haarer doode, etc., een stuk slands, groot Een hondert ackers, gelegen aan de Oostseide 
"van de riviere Zuriname, ter plaatse daar alsnu haare sinagogue "staat, naementlijk twintig kettingen op de face van de riviere, "soodat tien kettingen sich na beneeden en tien na booven strecken, "gaande voorts de rest landwaarts in, op welcke plaats (alsoo "deselve voor een gemeen lant wert gehouden en gereeckent) «een ieder sijne huisinge en erven sal vermoogen te setten en "hebben, en ook geene die aldaars bereeds haare huisingen en "erven hebben sullen deselve aldaar moogen behouden en on"bekommert genieten en behooren. Actum enz.»

Deze grondrief zal waarschijnlijk van vroegere zijn afgeschreven, zoodat wij hem gerust als het oorspronkelijk model mogen beschouwen.

Zoo eenvoudig zouden de grondbrieven echter op den duur niet blijven. Allengs werden er meer bepalingen in opgenomen. Vele daarvan hadden de strekking om de rechten van de Societeit tegenover de grondeigenaren te versterken. Zoo kon het niet anders of men ging later toch bij de W. I. C. in de leer, die om gelijke redenen haar feodale stelsel had ingevoerd en handhaafde. Daardoor kwamen er in de grondbrieven allerlei voorschriften, die een onmiskenbaar feodaal karakter hadden. Van dien aard waren de verplichtingen van den eigenaar tot het aanleggen en onderhouden van wegen, tot het schoonhouden van kreeken, tot verdediging van de kolonie tegen buitenlandsche vijanden en binnenlandsche onlusten en tot gehoorzaamheid aan de gegeven bevelen, alsmede zijn gehoudenheid om een zekere recognitie te betalen; voorts de bevoegdheid van den landheer om den uitgegeven grond geheel of ten deele te naderen, als die tot een ander oogmerk van algemeen belang noodig mocht zijn, en om hem in geval van verkoop te naasten; eindelijk het verval van het recht bij overtreding van de voorgeschreven bepalingen door den eigenaar. De landheer kon dan den grondbrief intrekken en den grond in den boezem van zijn domein doen terugkeeren.

De oudste grondbrieven, waarvan de tekst in het domeinarchief wordt aangetroffen, dagteekenen volgens de Gegevens (blz. 35) van 1743. ' Het recht van naasting bij verkoop kwam daarin reeds voor. De verplichting tot het betalen van een

1 Volgens het Rapport der Surinamecommissie blz. 114 dagteekent de oudste grondbrief in het domeinarchief uit 1699 . 
recognitie werd volgens Van Wieringen (bl. 196) sedert 1749 opgenomen in de uitgifte van de zoogenaamde "achterlanden" der plantages. Algemeen werd die verplichting krachtens de resolutie van 5 Maart 1755 , welke de betaling voorschreef van 2 stuivers Hollandsch per akker. Op grond daarvan wordt ook thans nog van de na 1755 uitgegeven gronden akkergeld geheven. De oudere plantages zijn daarvan vrij. Wanneer al die andere bepalingen zijn ingelascht, is aan schr. dezes niet bekend.

De uitgifte van land in Suriname is nooit grondig gewijzigd. Eigenlijk geschiedt zij thans nog op dezelfde wijze als onder de Societeit van Suriname. Het Koninklijk besluit van 20 December $1820, \mathrm{~N}^{\circ} 46$ (G. B. $1821 \mathrm{~N}^{\circ} 7$ ), stelde aan de hand van de destijds gebruikelijke bepalingen een model-grondbrief vast en dat model is, behoudens enkele wijzigingen van ondergeschikt belang, nog steeds van kracht. Het recht, dat uit dergelijke grondbrieven voortspruit, heet zooals voorheen: »allodiale eigendom en erfelijk bezit», maar ondanks de vooropstelling van de allodialiteit is het sterk feodaal gekleurd. Deze tegenstelling wordt echter niet meer gevoeld. Men vergelijkt den allodialen eigendom niet meer met feodale toestanden, waarvan men geen flauw besef meer heeft, doch met de bepalingen van het in 1868 ingevoerde Burgerlijk Wetboek en het tekort aan bevoegdheden, dat door die vergelijking aan het licht treedt, wordt toegeschreven aan het epitheton "allodiaal", dat in het wetboek niet wordt aangetroffen. Die bijstelling wordt in Suriname dan ook vrij algemeen als een beperking van het begrip eigendom beschouwd. Dat zij haar ontstaan juist te danken heeft gehad aan de begeerte om aan de grondbezitters, althans in beginsel, het meest uitgebreide recht te verzekeren, wordt door slechts weinigen bevroed. Tot die weinigen behoorden zelfs niet de officieele voorlichters van den Minister van Koloniën De Waal Malefijt. "De uitgifte geschiedde», zoo zeggen zij op blz. 104 van hun Rapport, "volgens het toen geldend recht, "in allodialen eigendom en erfelijk bezit, waardoor dus voor "de eigenaars de uitoefening van leenheerlijke rechten was uit"gesloten». Deze voorzichtig gestelde volzin is woordelijk een niets zeggende algemeenheid. Voor den eenigszins ingewijde is het echter duidelijk dat de stellers den allodialen eigendom van kolonialen grond niet als uitzondering maar als regel beschouwden en dat zij het belang er van niet in de uitgebreidheid van 
het recht, maar in de beperking daarvan — de uitsluiting van leenheerlijke rechten - zochten.

Bij eene herziening van de regelen betreffende de uitgifte van grond in de kolonie - waarvoor een commissie op het oogenblik bezig is plannen te ontwerpen - zal het dan ook niet noodig zijn daarin een principieele verandering aan te brengen, tenzij men de uitgifte in eigendom geheel zou willen doen vervallen, wat echter om verschillende redenen afkeuring zou verdienen. Want door het schrappen van de bijstelling "allodiaal» en van de toevoeging "erfelijk bezit» zal men slechts woorden doen vervallen, die in de tegenwoordige omstandigheden geen zin meer hebben en dus overbodig zijn. Ook de beperkingen van het recht, die men waarschijnlijk uit de oude grondbrieven in de nieuwe regeling zal willen overnemen en waaraan men wellicht nog andere zal wenschen toe te voegen, maken het volstrekt niet onmogelijk dat recht met «eigendom » te blijven aanduiden.
Amsterdam, Dec. '14.
G. J. FABIUS. 